Article

\title{
Experiencing and Teaching Pilgrimage in a Sacred Spaces Course
}

\author{
Thomas J. Sienkewicz \\ Monmouth College, Monmouth, IL 61462, USA; toms@monm.edu \\ Received: 28 February 2018; Accepted: 28 March 2018; Published: 30 March 2018
}

\begin{abstract}
As part of an integrated studies curriculum at the author's college, all juniors must take a Reflections course in which students consider personal values and analyze familiar and unfamiliar systems of thought and belief, in order to explore their own and others' ideas about the ultimate meaning and purposes of life. "Sacred Places Past and Present", is a course designed to fulfil this requirement. This course focuses on a number of important religious sites in the ancient Mediterranean and in the modern world, including the Parthenon, Olympia, Delphi, Stonehenge, and Muir Woods. These places are compared and contrasted in terms of what makes them sacred. Two pilgrimage experiences are part of this course: the hajj to Mecca and the Camino de Santiago de Compostela. In the past, the unit on the Camino focused on Emilio Estevez's 2010 film "The Way"; however, during the summer of 2016, the author walked the Camino de Santiago. As a result, the course was substantially revised to reflect the author's own personal experiences as a pilgrim. In particular, Paulo Coelho's The Pilgrimage was incorporated into the course and students were given an opportunity to participate in a one-day pilgrimage walk in western Illinois.
\end{abstract}

Keywords: Camino; Santiago; Coelho; hadj; Mecca; Estevez; sacred space; pilgrimage

At the author's college, all juniors must take a Reflections course in which students consider personal values and analyze familiar and unfamiliar systems of thought and belief, in order to explore their own and others' ideas about the ultimate meaning and purposes of life.

The Reflections course taught by the author, entitled Sacred Places Past and Present (Sienkewicz 2016) focuses on a number of important religious sites in the ancient Mediterranean and in the modern world. This paper gives a general overview of this course and focuses on the ways that pilgrimage has been integrated into the course discussion of sacred space, especially as a result of the author's personal experiences as a pilgrim walking the Camino de Santiago during the summer of 2016. Ideally, the course leads the students on a personal journey or pilgrimage in search of the places that are sacred to them in their lives.

This Sacred Places course is part of the college's unique and innovative general education program called "Integrated Studies" (Monmouth College 2017, p. 7). Students are required to take four integrated studies courses during their four-year college career. These four courses must be taken in sequence. In first year, students take a course called Introduction to the Liberal Arts, which orients them to the college and its emphasis on a liberal arts education. In sophomore year, they choose from a menu of Global Perspective courses designed to direct them to the world outside their own personal experience. In junior year, the course becomes more introspective and students reflect on concepts of thought and belief in terms of personal background and individual beliefs. Finally, in senior year, they turn to the theme of citizenship and are asked to consider their role as individual citizens in a global community. Many of these citizenship courses center around class projects which guide the students to responsible action on campus, or in the wider community. 
Students typically choose from a variety of topics for their Global Perspective, Reflections and Citizenship courses. In addition to this Sacred Places course, for example, Reflections course topics include Comparative Issues in World Religion, a History of Humanism, Christian Vocation, Self-Made Men, Machiavelli and Gandhi, and Physical Culture and Value.

While these Reflections topics are quite diverse, all are expected to focus on the same learning outcomes and goals. Students explore a variety of answers to issues of meaning and value. Students are also challenged in these courses to analyze these issues from a personal and critical point of view, and to recognize the broader historical, cultural, and social contexts upon which these issues are based. Finally, students are expected to develop their own personal views on these issues, and the impact they have on their own lives. In the case of the Sacred Spaces course, students are exposed to a variety of places which might be considered sacred; they are challenged to consider what makes these places sacred, and are asked to consider what places are sacred in their own lives and why.

At the beginning of the semester, students enrolled in the Sacred Places course are asked to share their initial understanding of the word "sacred" and their own sense of sacred place, and then to give an example of places they consider sacred in their own lives. Their responses are, in some ways, predictable and in other ways surprising. Students in the 2014 class defined the word "sacred" with words like "special", "important", "religious", "mythical", "memorable", and "valued". The things they felt made places sacred were the rituals performed there, significant events which occurred at the site, and the feeling or aura emanating from the place. Their examples of sacred places were sometimes personal and sometimes famous: their hometown church, a funeral home or a cemetery associated with a loved one, the Pyramids, Stonehenge, a Greek stadium, and even a forest. Toward the end of the course, students revisit their initial definitions and examples and reflect on how their views have changed over the course of the semester.

Since this course is taught by a Classicist, a significant portion of the course is devoted to comparing and contrasting the students' own sacred places with places in the ancient world such as the Acropolis in Athens, the shrine of Apollo at Delphi and the sanctuary of Zeus at Olympia. These ancient religious sites provide a relatively neutral context in which to discuss sacred space. The students who enroll in this course represent majors from across the college and a variety of religious backgrounds. Most, in fact, are essentially areligious, and few, if any, identify religiously with these places or are even familiar with them. The aim of the course is to have students use these places to reflect on their own sense of the sacred, and the connections they feel between space and sacredness.

In this part of the course, students read Sanctuaries and the Sacred in the Ancient Greek World (Pedley 2005), which offers not only studies of specific Greek sanctuaries such as Olympia, Delphi, Samos, Poseidonia, and the Athenian Acropolis, but also a good overview of the history of Greek sanctuaries, their locations, and various physical features (sanctuary walls, altars, and temples), as well as the kinds of rituals and ceremonies (festivals, sacrifices, meals, offerings, and contests) occurring at these places.

Students are encouraged to engage with Pedley's book in a number of ways. One way is an open-book chapter quiz or homework assignment. To give an example, as students read the chapter on Delphi, they are asked to determine which of the six types of sanctuary described by Pedley in an earlier chapter best describes Delphi. They are also asked to consider ways in which the geographic features of Delphi may determine its sacredness, and to find examples at Delphi of specific religious buildings and commemorative monuments. Finally, they reflect on Herodotus' famous story of Kleobis and Biton, and what that story suggests to them about the relationship between sacred places and deities, especially in the Greek world.

Another way is to have students work with Pedley chapter-by-chapter in small groups, and to make oral presentations to the rest of the class. A specific structure is provided for these reports, which must consist of a chapter summary, definitions of at least four central terms used there, and discussion of one image from that chapter. Each group is also asked to choose two meaty quotes from the chapter in order to discuss at least one way in which the Greek sense of sacred space 
stands out in the chapter. They must also provide a statement explaining what this chapter adds to their own sense of sacred space, and pose three questions for the class to discuss.

Attention is also given to sacred places outside the Classical world, such as the Dome of the Rock in Jerusalem, Stonehenge, the Vatican in Rome, and the Grand Mosque in Cordoba. Muir Woods is also considered as an example of a place of natural beauty. Such places are especially appealing to some students as an alternative to more formally religious sacred places.

A video entitled Mormon Temples: A Conversation with a Church Leader (Mormon Temples n.d.) is used to provide students with some background on the history of Mormon temples, and to give them a tour of a temple (since non-Mormons are not permitted to visit such a temple in person). This video is especially good at explaining how and why Mormons consider their temples to be sacred places.

Martin Grey's website entitled Places of Peace and Power (Grey n.d.) exposes the students to a broad geographic range of sacred places around the world. Grey also offers an excellent collection of essays entitled Sacred and Magical Places (Grey n.d.) which explores various ways in which the mysterious powers of such places are created and expressed. The topics of these essays range from the influence of sound and music or the use of aromatic substances and psychoactive plants, to celestial influences and sacred geometry. Students are assigned an individual essay to summarize for the class, after which they write response papers comparing the essay they were assigned to one or more of the essays on which their classmates have reported.

Mircea Eliade's view of the Sacred and Profane is also considered via a number of web resources, in particular John C. Durham's summaries of Eliade's work (Durham n.d.). While Eliade's views are somewhat challenging to many students, they do provide a more solid intellectual foundation for conversation.

Several weeks into the semester, when students are better positioned to think more deeply about their own sense of sacred space and their own religious or spiritual background, they are asked to "bare their souls" to each other, and to prepare a five-minute personal reflection which they share orally with the class, an exercise that is modeled by the professor. Students are often terrified at the thought of this assignment, but no one has ever refused to do it. Very often, after the class is over, students mention how valuable it was to hear their classmates and their professor share their backgrounds and spiritual beliefs.

Following this exercise, the connection between sacred places and pilgrimage is introduced with a unit on Mecca. The class watches an excellent National Geographic film entitled Inside Mecca (Inside Mecca 2003), which accompanies three pilgrims-one from Indonesia, another from Africa, and a third from the United States-as they travel from their homelands to Saudi Arabia. In order to aid the students in following the pilgrims along the various stages of the hajj-from Miquat to Mecca to Mina to Muzdalifah to the Plain of Arafat and back again-a map of the route (Wikitravel.org 2006) is provided, and students are asked to take notes about a list of various places and terms they encounter in the film. All of these terms are unfamiliar to most, if not all, of the students, so having a list in hand as they watch the film proves helpful in and of itself. Such note-taking also enables the students to focus on the film as an intellectual, rather than merely entertaining, experience. After they have seen the film, students write a reflection paper comparing Mecca as a sacred place to one of the other sacred places already discussed in the course.

In the following class, the students watch (Journey to Mecca 2008) which recounts the famous hajj of Ibn Battuta, whose 14th-century journey contrasts with and complements the 21-century hajjes depicted in the previous film. An excellent educator's guide for this film is available online (Gangopadhyay et al. 2009). This guide includes pre- and post-viewing questions, a glossary of terms, an interactive learning map, a timeline, a comparison of the hajj to pilgrimages in other world religions, a comparison of Ibn Battuta to Marco Polo, connections between the film and national teaching standards, and a list of further resources.

The next part of the course focuses on the Camino de Santiago de Compostela. This unit begins with a documentary film entitled Way of St. James (Camino de Santiago): The Temple of the Stars 
(Way of St. James 2015) which provides historical background on the shrine of St. James, the building of the great church, and the experiences of medieval pilgrims on their journey.

After the students watched this film in 2016, the instructor shared some personal experiences and motivation for walking the Camino. Included in this discussion were topics such as how many miles were walked, how many days it took to complete the Camino, and the variety of experiences along the way. In this discussion, special emphasis was placed on how the road itself became a "sacred place", in its combination of the very basic, simple meals and bodily sensations of weather, landscape, and walking long distances with visits to historical sites, churches, and personal encounters with other pilgrims. Watching a film about the Camino may provide students with a general perspective at a certain remove, but sharing the instructor's personal experiences brings them closer to a personal identification with the pilgrim experience.

Discussion of the instructor's Camino is followed by Emilio Estevez' The Way (Estevez 2011), which deals with the decision by a bereaved father to complete the Camino begun by his son, who died on the way. On his pilgrimage, the father befriends three other pilgrims who each walk for different reasons. This film is probably at least partly accountable for the growing popularity of the Camino in recent years. In fact, 2016, saw a record number of more than 275,000 pilgrims on the Camino (americanpilgrims.org 2017). Estevez' film enables the students to consider the Camino in the context of popular contemporary culture.

Another film to include in this unit is Phil's Camino (Philscamino.com 2016), Annie O'Neil's documentary film about a man suffering from advanced cancer who creates a Camino around his own property, where he walks the equivalent of the 500 miles across Spain to Santiago. His health eventually improves enough for him to walk the real Camino. In his review of this film, Yenis Monterrey (Monterrey 2016) says “The film is indeed a real journey, but more as an inner journey. As a viewer you will feel transported in the path of your own life with Phil. The emotional journey the viewer takes by watching the short documentary has a powerful and influential faith in healing".

The focus of the Camino unit, however, is Paulo Coelho's The Pilgrimage (Coelho 2008), originally published in 1987, which gives a fictionalized account of the author's own journey across northern Spain. The class reading of this novel is structured around chapter-by-chapter oral group reports of the book in which students offer meaty quotes from the chapter, three questions they would like the class to consider, and a concluding statement. Here, for example, is how students have explained the importance of the following quote they chose from Coelho's "Tradition" chapter: "... even if you become a Master, you have to realize that your road is one of many that lead to God.":

This is an important quote in this chapter because it basically summarizes everything that the narrator has to go through to reach the end of his journey He must walk his own path, unguided to truly find his end goal. There are many roads to God. Paolo must travel on his own to find his one path to God.

The Paolo the students refer to here is the name of the fictionalized narrator of Coelho's novel. Significant is the students' emphasis on the personal, individualized nature of Paolo's walk.

This group's concluding statement also gave a good summary of how the chapter advanced Coelho's physical and spiritual pilgrimage:

Even though he has done everything that has been asked of him, including participating in the tradition of those who keep alive the spirit of wisdom, he has still not found his sword. Now he has to finish the walk on his own. He will even have to guide someone else in the future .... There is so much more now that Paolo has to learn and teach that his journey will never truly stop. There will always be more for him to learn, even when he is teaching.

Coelho's book is supplemented by a video entitled Paulo Coelho on the Road to Santiago de Compostela (Paulo Coelho 2006). In this video (in Portuguese with English subtitles) Coelho himself reflects on his own Camino as he walks along the pilgrimage route and talks to other pilgrims. Watching and listening to the author has made students more engaged in reading Coelho's book. 
Coelho's book is also the focus of the common reflective writing assignment required in all Reflection courses at the college. While the specific topic for this assignment can be determined by the individual instructor, the exercise must be a significant part of the course, and be designed in such a way as to enable students to make observation(s), analyze them and then derive some meaning or implication from this analysis. The students' essays are submitted via Turnitin so that they can become part of personal writing portfolios for their integrated study courses. Students can thus look back on assignments from previous years and consider how they interconnect and demonstrate intellectual growth and progress. These essays are also used to assess composite student performance in various Reflection courses across the years, and may also serve as a means to evaluate the success of learning outcomes shared by all Reflections courses. This common reflective writing assignment was only recently introduced, so there is not yet sufficient data to draw any conclusions about its success.

Students in the Sacred Places course use Coelho's Pilgrimage to reflect on the concept of pilgrimage. They are encouraged in this assignment to draw comparisons between this book and other examples of pilgrimage discussed in the course, like the Camino itself, or the unit on Mecca.

Here is how one student used Coelho's book to reflect on pilgrimage:

Reading Paulo Coelho's The Pilgrimage enhanced my view of how a journey taken can be sacred as well as a place is sacred. Initially Paulo was taking this journey to find his sword but along the way he had to do exercises that would help him find his sword. While doing these exercises, Paulo had to challenge himself but found that they were all worth it. In the end he was able to find his sword but wouldn't have been able to do so without his journey on the Road .... . During the chapter about marriage Paulo talks to Antonio Manolo about soccer and asks him why he pays more attention to the fans rather than the game. Manolo explained to him that if the fans don't have faith that the team will win then they could lose a game they could have easily won. I thought that this tied in to the Road and the journey of the Road because if you and the people on the Road don't have the faith in the process of the Road than you won't get out of it what you could have potentially gotten if you had the faith of getting it the whole time. This showed me that having faith in things you do such as a pilgrimage can allow you to be more fulfilled from the process than just doing it to do it. This also enhanced my view on why a journey could be sacred because of the things you gain from it.

Significant here is the student's emphasis on the journey as sacred, and the importance of faith in the process of pilgrimage.

In 2016, it was also possible to offer students in this course a unique opportunity to participate in a real pilgrimage experience. The Catholic priest at the local parish organized a 17-mile "Walk to Mercy" from a church in Dallas City, Illinois, to a Holy Door at a church in Nauvoo. An added attraction was the chance to see the Mormon Temple in Nauvoo, at least from the outside. Two students from a class of 22 participated in the walk. One was a Syrian refugee who was a non-practicing Muslim. The other was an American agnostic with some affinity with Buddhism. Neither appeared to have had a significant religious experience on this walk. The American student said that he never wanted to see another cornfield, but would consider participating in another long walk in a different type of geographic area. The Syrian student said that it was a great experience for him because "it was the first time for me to participate in a religious practice that is not for my basic religion".

The last assignment and class meeting for this course consist of a final written statement and an oral report given by each student during the final exam period (instead of a final exam). In their oral reports, students are asked to reflect on how their own views of sacred places evolved over the course of the semester. Since these reports are given orally, specific student comments are not available, but most students did recognize in their reports that their understanding and appreciation of sacred place had changed and become more meaningful.

The final written reflection, like the common reflective writing assignment discussed earlier, is an assignment given to all Reflection students. Considered part of the final exam grade (or in my 
case combined with the final oral presentation grade), this assignment is designed to give students an opportunity to connect their Reflection course experience with their earlier integrated studies course, and to prepare them to consider ways in which the Reflection course might equip them for the Citizenship course taken in their senior year. Here is an excerpt from the written reflection submitted by the Syrian student mentioned earlier:

Before starting my reflection course I assumed that the idea behind it was to derive knowledge from our thinking. I was not wrong. Although I am a non-believer, I signed up for a course titled Sacred Places. For this course I participated in a Catholic Pilgrimage, and I reflected upon religious ideas as I learn about them. In my common reflection assignment I compared the book that we have to reflect on with another essay I was reading for one of my political science classes. While I was writing, I did not notice that I was learning from reflecting myself in this paper.... It was very pleasant to liberate my thoughts, to let them wander, and to let them find themselves and understand the way I act and feel. Since I am not religious and spirituality did not mean anything to me, I thought that I do not have a sense of spirituality or sacredness at all, and I was happy because I broke free from religions' handcuffs. But I learned that everyone has a kind of spirituality and a sense of sacredness, and it does not have to be religious... .

This student's reflection suggests that the course was, indeed, successful in meeting the stated learning outcomes of a Reflections course. The student demonstrated a knowledge of multiple answers to a significant value question; he was able to analyze this value question in terms of his own personal experience along with some understanding of a broader historical and cultural context, and to articulate his own views on this topic.

This overview of a Sacred Places course illustrates ways to expose students of varied backgrounds to different types of sacred space, and different ways to experience such sacred spaces through pilgrimage. The course is admittedly designed for a unique curriculum at a specific small U.S. liberal arts college, and contains features which reflect the particular academic interests and personal experiences of the instructor. Another instructor would most certainly teach this course differently. At a public institution, it might be more difficult to incorporate features such as personal religious reflections. Nevertheless, material and approaches are offered in this discussion which could successfully be adapted to the needs of other institutions.

Acknowledgments: This study was funded, in part, by a sabbatical grant from Monmouth College.

Conflicts of Interest: The author declares no conflict of interest.

\section{References}

americanpilgrims.org. 2017. Camino Statistics. Available online: http:/ /www.americanpilgrims.org/statistics (accessed on 16 September 2017).

Coelho, Paolo. 2008. The Pilgrimage, 2nd ed. San Francisco: HarperOne.

Durham, John C. n.d. Mircea Eliade: The Sacred \& the Profane. Available online: http:/ /www.bytrentsacred.co.uk/ index.php/eliade-sacred-and-profane (accessed on 16 September 2017).

Gangopadhyay, Paula, Carman Catherine, Ebersole Dorothy, and Kalinski Peter. 2009. Educators' Guide to Journey to Mecca. Available online: http://www.journeytomeccagiantscreen.com/media/JTM_Educators_ Guide.pdf (accessed on 16 September 2017).

Grey, Martin. n.d.a Places of Peace and Power. Available online: www.sacredsites.com (accessed on 16 September 2017).

Grey, Martin. n.d.b Sacred and Magical Places. Available online: https://sacredsites.com/sacred_places/sacred_ and_magical_places.html (accessed on 16 September 2017).

Inside Mecca. 2003. Washington, D.C.: National Geographic Society. Video. Available online: https://www. youtube.com/watch?v=PWhPSk5pfHg (accessed on 16 September 2017).

Journey to Mecca. In the Footsteps of Ibn Battuta. 2008. Toronto: SK Films. 
Monmouth College. 2017. Monmouth College Academic Catalogue 2017-2018. Monmouth: Monmouth College. Available online: http://ou.monmouthcollege.edu/_resources/pdf/academics/advising/catalog-20172018.pdf (accessed on 16 September 2017).

Monterrey, Yenis. 2016. The Documentary Short 'Phil's Camino' SXSW 2016-Review. Available online: http:/ / www. lasplash.com/publish/686-New-Talent/the-documentary-short-phil-s-camino-sxsw-2016.php (accessed on 16 September 2017).

Mormon Temples: A Conversation with a Church Leader. n.d.. Salt Lake City: Church of Jesus Christ of Latter-Day Saints, Video. Available online: https:/ / www.lds.org/temples/conversation-with-church-leader?lang=eng (accessed on 16 September 2017).

Paulo Coelho on the Road to Santiago de Compostela. 2006. Oslo: Nordic World. Film. Available online: https: / / www.youtube.com/watch?v=51SyWAMk8LI (accessed on 16 September 2017).

Pedley, John. 2005. Sanctuaries and the Sacred in the Ancient Greek World. Cambridge: Cambridge University Press.

Philscamino.com. 2016. Phil's Camino. USA: Annie O’Neil. Film. Available online: http://philscamino.com/ (accessed on 16 September 2017).

Sienkewicz, Thomas J. 2016. Sacred Places Past and Present. Available online: http:/ / department.monm.edu / classics / Courses / Reflections/2016.htm (accessed on 16 September 2017).

The Way. 2011. Directed by Emilio Estevez. Los Angeles: Icon Entertainment International. Film.

Way of St. James (Camino de Santiago): The Temple of the Stars. 2015. Planet Doc. Video. Available online: https: / / www.youtube.com/watch?v=blK3IF51B0M (accessed on 16 September 2017).

Wikitravel.org. 2006. Hajj Route. Available online: http://wikitravel.org/en/File:Hajj1.gif (accessed on 16 September 2017).

(C) 2018 by the author. Licensee MDPI, Basel, Switzerland. This article is an open access article distributed under the terms and conditions of the Creative Commons Attribution (CC BY) license (http:/ / creativecommons.org/licenses/by/4.0/). 